\title{
Assessment of noise level emitted by micro tractor in static and dynamic conditions
}

\section{Avaliação do nível de ruído emitido por um microtrator em condição estática e dinâmica}

\author{
Elivânia Maria Sousa Nascimento ${ }^{1 *}$; Carlos Alberto Viliotti²; \\ Renildo Luiz Mion³; Daniel Albiero²; Leonardo de Almeida Monteiro²
}

\begin{abstract}
Noise is a complex mixture of sounds that causes the feeling of discomfort and is continuously present in the daily lives of human beings. The objective of this study is to assess the noise level emitted by a micro tractor in various situations. In the first situation, the micro tractor is standing still and is subjected to 600,800 , and $1100 \mathrm{rpm}$ from four positions -right, front, left, and rear sides -as well as four distance radii $-1,2,5$, and $10 \mathrm{~m}$. In the second situation, the micro tractor is in motion and is subjected to three operational gears (1st, 2nd, and 3rd) at $1100 \mathrm{rpm}$ with two types of soil surfaces -hard and mobilized. The results reveal that noise levels increase with an increase in the number of engine rotations and they decrease with an increase in the distance radius; this can be observed in all three situations considered in the assessment. Further, it is verified that there is no difference between surfaces in terms of the noise level, and the average value for the hard soil and mobilized soil is $89.5 \mathrm{~dB}(\mathrm{~A})$ and $91.7 \mathrm{~dB}(\mathrm{~A})$, respectively. However, for both surfaces, the values are above the threshold of $85 \mathrm{~dB}(\mathrm{~A})$ for an eighthour work shift.
\end{abstract}

Key words: Noise level, ergonomics, machines

\section{Resumo}

O ruído é um complexo de sons que causam sensação de desconforto e está presente de forma contínua na vida diária dos seres humanos. Objetivou-se com este trabalho avaliar o nível de ruído emitido por um microtrator sob diferentes situações: a primeira com o microtrator parado submetido às rotações de 600, 800 e 1.100 rpm em quatro posições em relação ao microtrator: lados direito, frontal, esquerdo e traseiro e quatro raios de afastamento: $1,2,5$ e $10 \mathrm{~m}$ e a segunda com o microtrator em movimento submetido a três marchas de trabalho $\left(1^{\mathrm{a}}, 2^{\mathrm{a}}\right.$ e $\left.3^{\mathrm{a}}\right)$ a uma rotação de $1.100 \mathrm{rpm}$ em duas superfícies de solo (firme e mobilizado). Os resultados mostraram que o nível de ruído aumenta com um incremento da rotação do motor e diminui à medida que o raio de afastamento aumenta, isso pode ser observado para as três rotações avaliadas. Verificou-se que não há diferenças entre as superfícies, para o nível de ruído, sendo o valor médio para o solo firme de $89,5 \mathrm{~dB}(\mathrm{~A})$ e de $91,2 \mathrm{~dB}(\mathrm{~A})$ para o solo mobilizado, mas em ambas as superfícies, os valores estão acima do limite de $85 \mathrm{~dB}(\mathrm{~A})$ para uma jornada de oito horas.

Palavras-chave: Nível de ruído, ergonomia, máquinas

\footnotetext{
${ }^{1}$ Enga Agr $^{\mathrm{a}}$, M.e. em Engenharia Agrícola, Dept ${ }^{\mathrm{o}}$ de Engenharia Agrícola, Universidade Federal do Ceará, UFC, Bloco 804, Campus do Pici, Fortaleza, CE. E-mail: elivania_sousa@yahoo.com.br

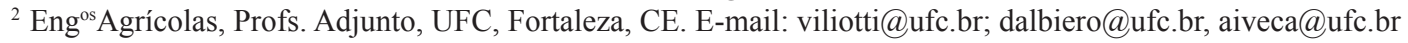

${ }^{3}$ Eng $^{\mathrm{o}}$ Agrícola, Prof. Adjunto, Instituto de Ciências Agrárias e Tecnológicas, Universidade Federal do Mato Grosso, UFMT, Rondonópolis, MT. E-mail: renildomion@gmail.com

* Author for correspondence
} 


\section{Introduction}

Noise is a complex mixture of sounds that causes the feeling of discomfort and is continuously present in the daily lives of human beings (KROEMER; GRANDJEAN, 2005). The presence of noise during a work shift may harm the auditory system of workers and cause loss of hearing when the noise levels are excessive (TELES, 2009). In addition to problems regarding hearing, increased levels of noise may lead to disorders such as irritability, fatigue, and sleep disorders (SILVA, 2002).

The exposure time, sound level, frequency, noise intensity, and the susceptibility of the individual is directly related to the severity of the worker's illnesses, making him/her more susceptible to accidents and health issues (DEWANGAN; PRASANHA-KUMAR; TEWARI, 2005).

Intense noises tend to adversely affect tasks demanding mental concentration and certain tasks that require attention or speed and motion accuracy; the effects tend to worsen after two hours of noise exposure (ALMEIDA; ILGNER; RUSSO, 2001).

Currently, there are several standards that establish the acceptable standards for noise levels. One of the main international standards is ISO 5131 (ISO, 1982). In Brazil, the Brazilian Association of Technical Standards (Associação Brasileira de Normas Técnicas - ABNT) has some standards regarding noise levels for agricultural machines, and the main standards are NBR 9999 (ABNT, 1987a) and NBR 1052 (ABNT, 1987b).

According to the ABNT Standard NBR 1052, when an individual is exposed to high noise levels, the entire system reacts to such stimuli, and this may reflect in physiological, biochemical, and cardiovascular aspects; additionally, it can reflect in the psychological behavior of the individual.

The Regulatory Standard (NR-15) regarding unhealthy operations and activities, established by Ordinance 3.214/78 of the Department of Labor and Employment (MTbE), states that the maximum noise level allowed for a daily exposure of eight hours is $85 \mathrm{~dB}(\mathrm{~A})$ (BRASIL, 2011). Above this threshold, the noise, in addition to disturbing human activities, may cause serious health damage (SILVA et al., 2004).

Fernandes (1991) analyzed noise sources from agricultural tractors and concluded that the main cause of the noise is the engine, particularly the exhaust system. Kahil and Gamero (1997) determined that noise levels emitted by micro tractors, measured within the hearing range of the operator, were above what is permissible by law for a work shift of eight hours.

Delmond and Reis (2006) assessed the noise levels emitted by tractors in various agricultural activities, and according to the authors, noise can be considered among the worst environmental factors that are damaging to rural workers.

In a work conducted by Souza, Fernandes, and Vitória (2004), the noise level produced by a bean harvesting machine was assessed, and it was concluded that the noise levels emitted in the reviewed cases were above the $85-\mathrm{dB}(\mathrm{A})$ threshold for the daily exposure of eight hours established by standard NR-15, which serves as evidence of the severity of the problem in rural settings.

The solution for the problem of the noise emitted by tractors not only consists of acoustic insulation but also a change in the attitude of manufacturers towards investment in the research on noisegenerating sources with the goal of decreasing them (MIALHE, 1996).

The objective of this study is to assess the noise emitted by a micro tractor in various situations. In the first situation, the micro tractor is standing still and is subjected to 600,800 , and $1100 \mathrm{rpm}$ from four positions-right, front, left, and rear sides-as well as four distance radii- $1,2,5$, and $10 \mathrm{~m}$. In the second situation, the micro tractor is in motion and is subjected to three operational gears (1st, $2 \mathrm{nd}$, and 3rd) at $1100 \mathrm{rpm}$ with two types of soil surfaces (hard and mobilized). 


\section{Materials and Methods}

The assays were conducted in an experimental area belonging to the Federal University of Ceará located in the city of Fortaleza, Ceará, coordinates $03^{\circ} 43^{\prime} 02^{\prime \prime} \mathrm{S}$ and $38^{\circ} 32^{\prime} 35^{\prime \prime} \mathrm{W}$. The soil in the experimental area is classified as Red Yellow Acrisol (EMBRAPA, 2006).

As the power source, a micro tractor of the Yanmar Agritech brand with a nominal power of $10.3 \mathrm{~kW}$ was used. In order to assess the noise level, an Instrutherm personal dosimeter model DOS-500 was used for obtaining the readings of the micro tractor when it was standing still and when it was in motion, and a Minipa digital decibel meter model MSL-1350 was used for obtaining the external readings in various positions and for various distance radii.

In the static condition, the noise level was measured near the ear of the operator with the micro tractor subjected to 600,800 , and $1100 \mathrm{rpm}$ from four positions-right, front, left, and rear sides-and four distance radii-1, 2, 5, and $10 \mathrm{~m}$. In the dynamic condition, the micro tractor was subjected to three operational gears (1st, 2nd, and 3rd) at $1100 \mathrm{rpm}$ on two types of soil surfaces (hard and mobilized). The assessments were conducted following the methodology described by standard NBR 9999 (ABNT, 1987a) according to which the ambient temperature of the assay was between -5 and $30^{\circ} \mathrm{C}$ and the wind speed was less than $5.0 \mathrm{~ms}^{-1}$.

The measurement of the noise level with the micro tractor standing still was conducted by stabilizing the engine rotation and then taking the reading. The procedure was repeated five times for each established rotation. In order to analyze the data, the rotational levels tested were considered to be quantitative factors with five repetitions for each of them. In order to gain insight into the effect of engine rotation on the noise measured, it was necessary to conduct a linear regression and respective variance analysis by adopting a significance level of 5\%.

In order to conduct the external measurement, the micro tractor was placed in a field that was free of sound pollution, which would have interfered with the measurements. Noise-level measurements were conducted at the height of the operator's ear with an interval of $5 \mathrm{~s}$ between the reading and its repetition. In order to analyze the data, a descriptive statistical data analysis was conducted using Microsoft Excel 2010 .

Noise-level measurements when the micro tractor was in motion were conducted near the operator's ear during the lap time in the intervals. In order to analyze the data in this case, the factorial scheme of two factors in completely randomized delineation (CRD) was used with two types of surfaces (hard soil and mobilized soil), and three operational gears (1st, 2nd, and 3rd) after three repetitions. When the data were significant at $5 \%$ of the probability in the F test, the Tukey test was applied to compare the mean values.

\section{Results and Discussion}

The noise levels emitted by a micro tractor that was standing still and measured near the operator's ear for each one of the assessed rotations are presented in Table 1 along with a statistical description of the data.

The chart result of the linear regression analysis and the straight-line adjustment equation are shown in Figure 1. The regression variance analysis showed that there was a significant effect of the rotation of the engine on the noise levels experienced by the operator. As the number of rotations increased, there was a corresponding increase in the noise level. The correlation coefficient of the data and the adjusted straight line was higher than 0.99 . 
Table 1. Statistical descriptive summary of the noise levels $(\mathrm{dB}(\mathrm{A}))$ emitted by measured near the operator's in the rotations 600,800 e $1100 \mathrm{rpm}$.

\begin{tabular}{cccc}
\hline & \multicolumn{3}{c}{ Rotation $(\mathrm{rpm})$} \\
\cline { 2 - 4 } Repetition & 600 & 800 & 1.100 \\
\hline 1 & 84,3 & 87,8 & 90,4 \\
2 & 81,4 & 85,8 & 91,2 \\
3 & 84,6 & 87,2 & 91,8 \\
4 & 83,8 & 88,1 & 90,8 \\
5 & 84,8 & 87,6 & 92,8 \\
\hline Average (dB(A)) & 83,7 & 87,3 & 91,4 \\
SD (dB(A)) & 1,4 & 0,9 & 0,9 \\
VC (\%) & 1,7 & 1,0 & 1,0 \\
\hline
\end{tabular}

$\mathrm{SD}$ : standard deviation, CV: coefficient of variation.

Source: Elaboration of the authors.

Figure 1. Result of the linear regression analysis and the straight-line adjustment of the noise levels by micro tractor rotations different.

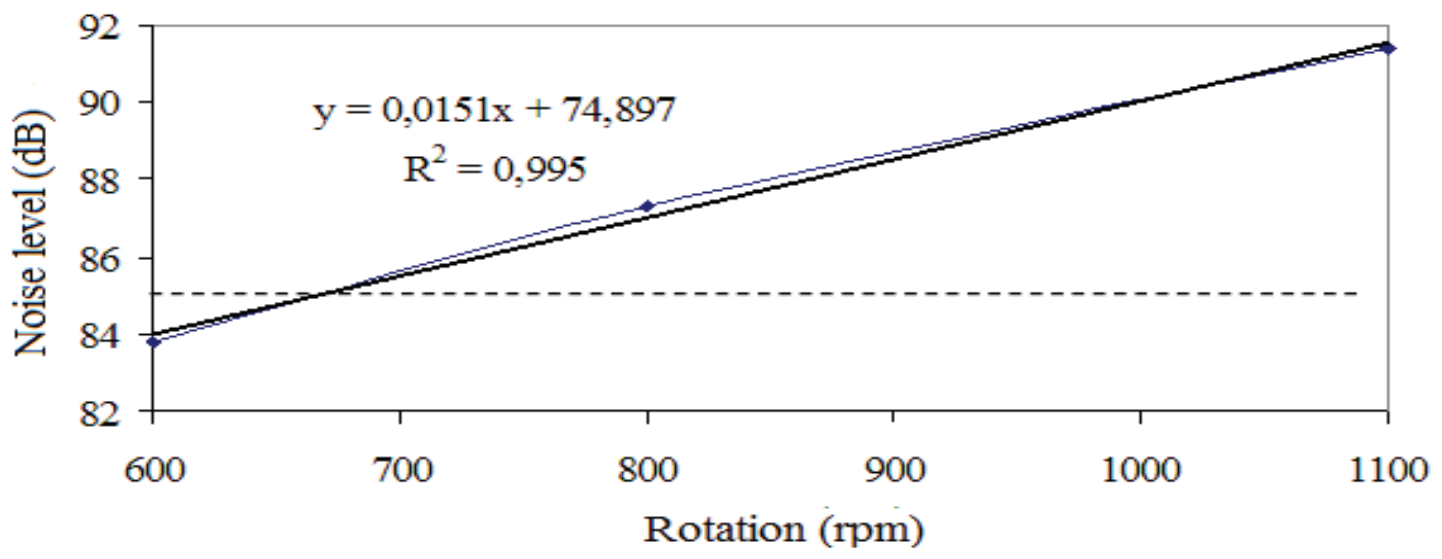

Source: Elaboration of the authors.

In Table 2, the maximum exposure time of the operator is given for each of the assessed rotations according to standard NR-15, which establishes the daily maximum exposure values for fluctuating or continuous noises. It is noted in Table 2 that the micro tractor assessed at 800 and $1100 \mathrm{rpm}$ does not provide safe conditions for the health of the operator if used for a period that exceeds the maximum exposure time allowed for an eight-hour work shift. Only in the case of $600 \mathrm{rpm}$ (Figure 1) is it possible to operate the micro tractor during the normal work shift without any damage caused to the operator's hearing.
In Figure 2, the behavior of the external noise levels is shown when the micro tractor stopped at 600,800 , and $1100 \mathrm{rpm}$; these noises were emitted at a distance of $1,2,5$, and $10 \mathrm{~m}$ on all four sides of the micro tractor. It is observed that the noise levels increase with an increase in the number of engine rotations, and they decrease with an increase in the distance radius; this can be observed for all three rotations in the assessment. The dashed line represents the maximum exposure threshold that the worker can be exposed to according to standard NR-15. 
Table 2. Maximum exposure daily time of the operator is given for each of the assessed rotations.

\begin{tabular}{cccc}
\hline Rotation $(\mathrm{rpm})$ & 600 & 800 & 1.100 \\
\hline Noise levels measured (dB) & 83,7 & 87,3 & 91,4 \\
Maximum exposure time (h) & - & 6 & 3 \\
\hline
\end{tabular}

Source: Elaboration of the authors.

Figure 2. Average value of the noise levels emitted by micro tractor in function of the distance radius in position different in the rotations of the 600 (a), 800 (b) e $1.100 \mathrm{rpm}$ (c).

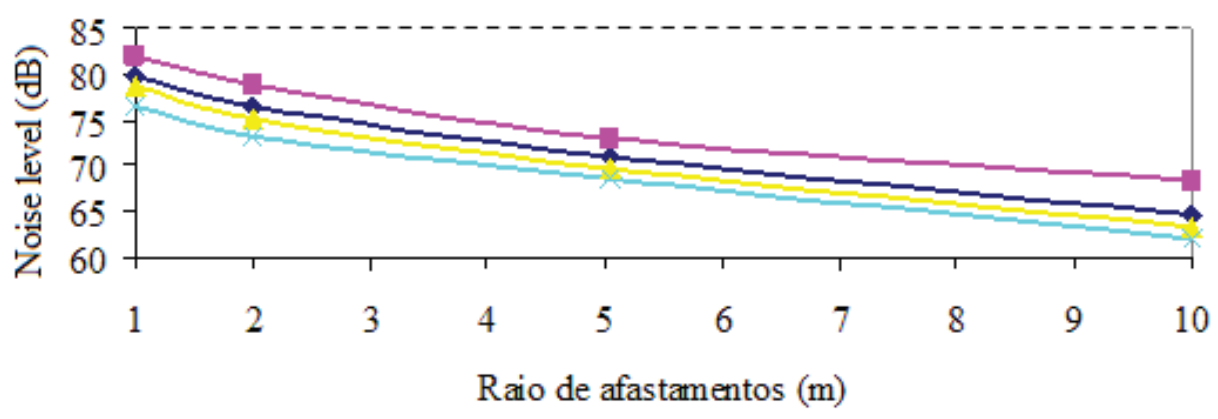

$\multimap \bullet$ Right side $\quad \rightarrow-$ Left side $\quad \rightarrow$ Front side $\leftarrow$ Rear side

(a)

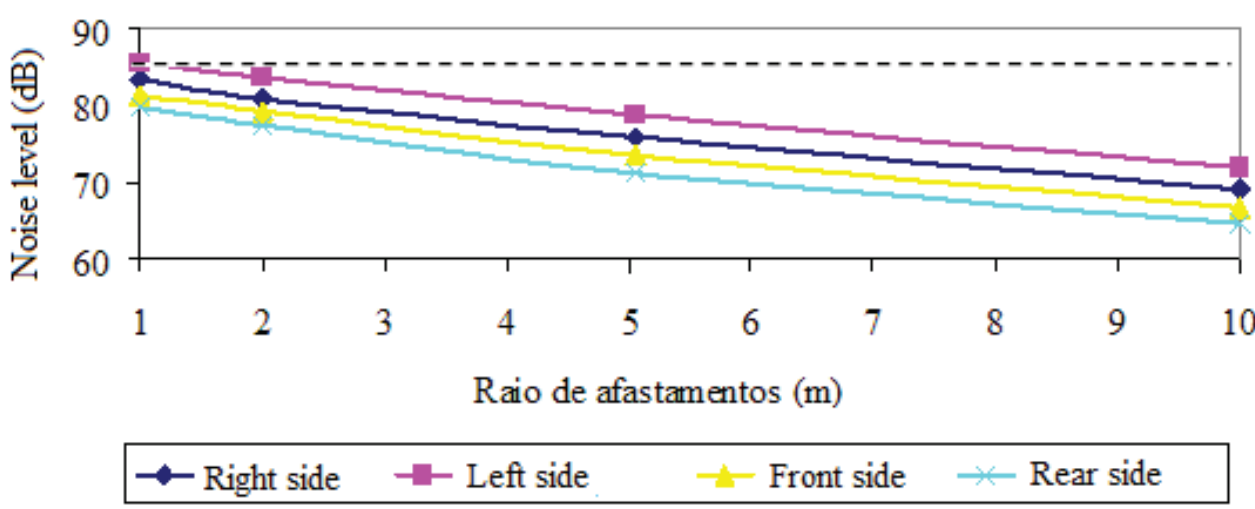

(b)

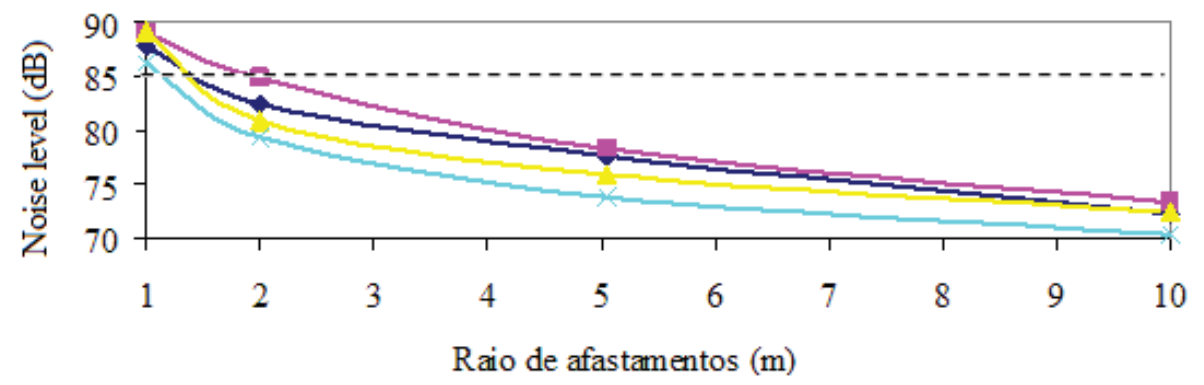

Right side $\quad \rightarrow$ Left side $\quad \rightarrow$ Front side $\leftarrow$ Rear side

(c)

Source: Elaboration of the authors. 
In the case of $600 \mathrm{rpm}$, the noise level was below the value recommended by standard NR-15 $(85 \mathrm{~dB}(\mathrm{~A}))$ in all directions of the micro tractor. In the case of $800 \mathrm{rpm}$, this value was only found from the left side $(85.6 \mathrm{~dB}(\mathrm{~A}))$ at a distance of 1 $\mathrm{m}$. In the case of $1100 \mathrm{rpm}$, the noise levels were 89.2, 88.9, 87.8, and 86.2 $\mathrm{dB}(\mathrm{A})$ in the front, left, right, and rear directions, respectively, and the use of the earpieces was recommended for individuals who were within the considered distance radius. It was also observed that the noise level was higher in the front and on the left of the micro tractor. This could be attributed to the fact that this is where the exhaust and transmission system, consisting of engine chains and pulleys, is found; considering that the wind direction was towards the front of the micro tractor, such a condition might have favored the observation of relatively high values in this direction.

Ruas et al. (2011) assessed the effect of rotation on various measurement positions and determined that the highest noise levels occurred when the number of engine rotations was increased. These researchers also observed that the highest noise levels were obtained in the front and on the left of the micro tractor.

Silveira, Tieppo, and Gabriel Filho (2008) assessed the noise levels due to an agricultural tractor operating with minimal preparation because of the shifting of the gears and the engine rotation, and determined that the noise levels increased because of the engine rotation.

Noise emitted by a tractor in motion can be observed using a comparison of the variance synthesis of the soil surface and the operational gears (Table 3). It was verified that there was no difference in the noise level due to the surface, and the average value for the hard soil and mobilized soil was 89.5 $\mathrm{dB}(\mathrm{A})$ and $91.7 \mathrm{~dB}(\mathrm{~A})$, respectively. However, for both surfaces, the values were above the threshold of $85 \mathrm{~dB}(\mathrm{~A})$ for an eight-hour work shift according to standard NR-15. Further, the contribution of the operational gears was significant (1\%). There was no significant effect of the interaction between the soil surface (hard and mobilized) and the operational gears, indicating that there are differences within factors.

Table 3. Analysis variance synthesis of the average value noise levels in function soil surface and the operational gears.

\begin{tabular}{cc}
\hline Factors & Levels noise $(\mathrm{dB}(\mathrm{A}))$ \\
\hline Soil surface (S) & 89,5 \\
Hard & 91,2 \\
Mobilized & \\
Gear (M) & $87,3 \mathrm{~b}$ \\
M1 & $91,4 \mathrm{a}$ \\
M2 & $92,1 \mathrm{a}$ \\
M3 & $3,78 \mathrm{~ns}$ \\
F Test & $17,11 * *$ \\
S & $0,60 \mathrm{~ns}$ \\
M & 1,12 \\
S x M & CV (\%)
\end{tabular}

For each factor, means followed by the same lower-case letter in the column do not differ by the Tukey test, at 5\% of probability, and means not followed by any letter imply an interaction between factors ns - Non-significant $(\mathrm{p}>0,05)$;

* - Significant $(\mathrm{p}<0,05) ; *$ - Significant $(\mathrm{p}<0,01)$; C.V. - Coefficient of variation.

Source: Elaboration of the authors. 
Tosin, Lanças, and Araújo (2009) conducted a research using two tractors for studying the conditions of the track, asphalt, hard soil, and concrete, using four distinct tire inflation pressures of the tractors and three operational gears, and determined that the noise generated by the tractor was not influenced by the type of soil, the tire inflation pressure, and the average speed.

Arcoverde et al. (2011) conducted a study using two assay tracks (prepared soil and soil covered by weeds) and five displacement speeds $(0.83,1.39$, $2.42,2.97$, and $3.61 \mathrm{~ms}^{-1}$ ) and noted that relatively low-speed gears caused relatively higher noise levels when the tractor traveled on soil covered by weeds.

Baesso et al. (2008), who worked on the effects of an air-assisted and non-air-assisted spray gun, observed that the noise level near the operator's ear was above the threshold permissible by standard NR-15, emphasizing that individuals exposed to 82 , 85,88 , or $92 \mathrm{~dB}(\mathrm{~A})$ in a daily work shift lose 2,5 , 10 , or $20 \%$ of their hearing, respectively.

\section{Conclusions}

The noise level measured near the operator's ear when the micro tractor was standing still increased when rotations were higher, and decreased with an increase in the distance radius.

The noise levels near the operator in field conditions were 89.5 and $91.2 \mathrm{~dB}(\mathrm{~A})$ for hard and mobilized soil, respectively, and the values were above the threshold established by the standard regarding the maximum exposure time of eight hours a day without the use of earpieces.

The use of earpieces is recommended for machine operators and field assistants while working with micro tractors within a distance radius of $1 \mathrm{~m}$ when rotations are higher.

\section{References}

ASSOCIAÇÃO BRASILEIRA DE NORMAS TÉCNICAS -ABNT. NBR 9999: medição do nível de ruído, no posto de operação de tratores e máquinas agrícolas. Rio de Janeiro, 1987a. 21 p.

. NBR 1052 (NB 95): níveis de ruído para conforto acústico. Rio de Janeiro, 1987b. 4 p.

ALMEIDA, D. S.; ILGNER, N. O.; RUSSO, S. Determinação e análise dos níveis sonoros nos habitáculos de colhedoras agrícolas. Rio Grande do Sul: Universidade Regional Integrada do Alto Uruguai e das Missões, 2001.

ARCOVERDE, S. N. S.; CORTEZ, J. W.; PITANGA JÚNIOR, C. O.; NAGAHAMA, H. J. Nível de ruído emitido por conjuntos mecanizados em função da velocidade e da condição do solo. Revista Brasileira de Ciências Agrárias, Recife, v. 6, n. 3, p. 514-520, 2011.

BAESSO, M. M.; TEIXEIRA, M. M.; RODRIGUES JÚNIOR, F. A.; MAGNO JÚNIOR, R. G.; FERNANDES, H. C. Avaliação do nível de ruído emitido por um conjunto trator pulverizador com e sem assistência de ar. Engenharia na Agricultura, Viçosa, v. 16, n. 4, p. 400407, 2008.

BRASIL. Ministério do Trabalho e Emprego. Atividade e operações insalubres. NR 15. 2011. Disponível em: <http://www.mtb.gov.br/legislacao/ normas regulamentadoras/nr_15.pdf $>$. Acesso em: 18 nov. 2011.

DELMOND, J. G., REIS, E. F. dos. Avaliação de níveis de ruído emitidos por tratores em diferentes operações agrícolas. In: SEMINÁRIO DE INICIAÇÃO CIENTÍFICA, 4., 2006. Anais... UEG, 2006. p. 7-12. Disponível em: <http://www.prp.ueg.br/06v1/ctd/pesq/ inic_cien/eventos/sic2006/arquivos/agrarias/avaliacao_ niveis.pdf $>$. Acesso em: 14 fev. 2012.

DEWANGAN, K. N.; PRASANNA-KUM AR, G. V.; TEWARI, V. K. Noise characteristics of tractors and health effect on farmers. Applied Acoustics, London, v. 66, n. 9, p. 1049-1062, 2005.

EMPRESA BRASILEIRA DE PESQUISA AGROPECUÁRIA - EMBRAPA. Centro Nacional de Pesquisa de Solos. Sistema Brasileiro de Classificação de Solos. 2. ed. rev. atual. Brasília, DF: Embrapa Produção da Informação; Rio de Janeiro: Embrapa Solos, 2006. $306 \mathrm{p}$.

FERNANDES, J. C. Avaliação dos Níveis de Ruído em tratores agrícolas e seus efeitos sobre o operador. 1991. Tese (Doutorado em Energia na Agricultura) - Faculdade de Ciências Agronômicas. Universidade Estadual Paulista, Botucatu. 
INTERNATIONAL STANDARD ORGANIZATION ISO. Norma ISO 5131: acoustics - tractors and machinery for agriculture and forestry - measurement of noise at the operator's position. St. Joseph, 1982. 8 p.

KAHIL, M. A.; GAMERO, C. A. Níveis de ruído: avaliação ergonômica de alguns tratores e equipamentos agrícolas. Energia na Agricultura, Botucatu, v. 12, n. 3, p. 46-53, 1997.

KROEMER, K. H. E.; GRANDJEAN, E. Manual de ergonomia: adaptando o trabalho ao homem. 5. ed. PortoAlegre: Bookman, 2005.

MIALHE, L. G. Máquinas agrícolas ensaios e certificação. Piracicaba: Fundação de estudos agrários Luiz de Queiroz, 1996. 723 p.

RUAS, R. A. A.; MACHADO, R. A. A.; MACHADO, L. G.; CAIXETA, L. F.; DEZORDI, L. R.; RUAS, S. R. C. Determinação do raio de afastamento seguro de acordo com o nível de ruído produzido por um micro-trator. Global Science and Technology, Goiás, v. 4, n. 1, p.124$130,2011$.

SILVA, L. F. Estudo sobre a exposição combinada entre ruído e vibração de corpo inteiro e os efeitos na audição dos trabalhadores. 2002. Tese (Doutorado em Saúde Ambiental) - Faculdade de Saúde Pública. Universidade de São Paulo, São Paulo.
SILVA, R. P.; FONTANA, G.; LOPES, A.; FURLANI, C. E. A. Avaliação do nível de ruído em colhedoras combinadas. Revista Engenharia Agrícola, Jaboticabal, v. 24, n. 2, p. 381-387, 2004.

SILVEIRA, J. C. M.; TIEPPO, R. C.; GABRIEL FILHO, A. nível de ruído emitido por um conjunto motomecanizado na operação de preparo mínimo do solo. Global Science and Technology, Goiás, v. 1, n. 8, p. 60-70, 2008.

SOUZA, L. H.; FERNANDES, H. C.; VITÓRIA, E. L. Avaliação dos níveis de ruído emitidos por diferentes conjuntos mecanizados. Revista Brasileira de Saúde Ocupacional, São Paulo, v. 28, n. 105-106, p. 21-30, 2004.

TELES, C. J. C. F. Avaliação do grau de conhecimento dos médicos dentistas em relação à aplicação da ergonomia na medicina dentária. 2009. Monografia (Medicina Dentária) - Universidade Fernando Pessoa, Porto.

TOSIN, R. C.; LANÇAS, K. P.; ARAUJO, J. A. B. Avaliação do ruído no posto de trabalho em dois tratores agrícolas. Revista Energia na Agricultura, Botucatu, v. 24, n. 4, p. 108-118, 2009. 